\title{
LIBRARY CONSORTIA SPECIAL REFERENCE TO ENGINEERING COLLEGE LIBRARY: A STUDY OF WEST BENGAL
}

\author{
Mr. UTTAM KUMAR GHOSH ${ }^{1} \&$ Dr. KUMKUM RAJAWAT ${ }^{2}$ \\ ${ }^{1}$ Research Scholar, Maharaj Vinayak Global University, Jaipur, India \\ ${ }^{2}$ Assistant Librarian, Sardar Patel Medical College, Bikaner, India
}

\begin{abstract}
This study has portrayed the association of libraries and how it is given that great consequences on the Engineering athenaeum and their particular users. Involvement Resources among Libraries is necessary for reasons like budget constraints, space problem, raising the cost of E-Resources and to make available continuous information access. Library Consortia are another source to tide over the financial Constraints. Consortia is a kind of Co-Operation among libraries that come together to share E-Resources. This concept has originated from Library Co-Operation. The member Libraries of any Consortia are to share their information resources under a legal agreement. Therefore, access to information among participated libraries in consortia is easy and possible.

KEYWORDS: Library Consortia Special Reference To Engineering College Library
\end{abstract}

Received: Jun 10, 2020; Accepted: Jun 30, 2021; Published: Jun 30, 2021; Paper Id.: IJLSRDEC20213

\section{INTRODUCTION}

The information centre gives books and assets and it is easily available for every student. All of them are able to continue their studies by taking books from the media centre. In this respect, engineering fresher's can easily collect their notes from there and also it's a place where individuals have the scope to study collectively. Recent studies show that this bibliotheca is not capable of giving all their needed books, journals and papers accordingly as they are not available in their library. The main reason behind that, there is an issue of funds and management that cannot take care of all departments in this particular section. It gives trouble to both the students and members of the college in the state of West Bengal. There are needs for present day automation as it helps a lot to solve these types of issues accordingly. The digital format materials are very useful and helpful in this particular matter as it gives their opportunity to connect with each other and work more progressively.

It gives so many beneficial effects to this athenaeum to connect with other information centres completely that in an emergency case both can help each other well. It gives offers to the bibliotheca to share and also gather companions from other sources and can easily take books from other athenaeum and similarly gives them also. It gives beneficial effects to the students as all of them easily collect the needed reference book and also librarians give them easily. Similarly, if it is not present in their centre through the digital medium, it easily orders from the other libraries. It gives a platform to digital book centres to their students where each individual fresher easily finds out their needed reference book by using this system and easily accesses whether this particular item is present in their centre or not.

The administrator easily accesses these links and through this networking orders this from other studies 
accordingly. This medium is provided with so many beneficial effects and on the contrary, it takes high cost. This is a drawback as without financial support all of them cannot use this system for their progress. It is vital to raise funding so that this networking is implemented in their centre properly. On that, to remove or reduce these matter consortia is the best solution and that needs to be implemented well by all centres. The association mainly depicted that two or more libraries joined, performed together and helped each other well. All of them share their assessment with others and easily access their important particulars. It does not need so many funds as all of them cooperatively and co-ordinately worked together.

It gives advantageous factors to all of them as it is cost effective and helps to improve their services well. In this respect, by using this system all curators give good and better assistance to all their students and it raises the power of their work as a group. It raises the probability of working together more than 2 or 3 athenaeum and similarly, raises community to their part accordingly. It improves their services and it helps to raise their users to greater numbers. It also helps to increase their collection of guides and gives them to all their customers. This council needs some procedures so that all centres can easily add their names with their bibliotheca correctly in this system. It needs some contribution charges for enrolling their names on this board. It focuses on other facts that if the number of users gets increased day by day, the cost of enrolling gets also shared with everyone and it ultimately helps to reduce the amount of charges well. This system is really beneficial as it helps everyone to work as a group and helps each other and also works more dedicatedly and collectively. It helps librarians to fulfil all needs of their users accordingly and gives the best ministry to all of them.

\section{LIBRARY CONSORTIA}

This council is mainly focused to improve functions of book collection properly. It depicted that, working together helps a lot to solve issues of an individual well and supports each other correctly. It indicates that every centre needs to work collaboratively so that it gives the best services to their clients. It improves their plan of action and helps to gather more reference books from other information centres. It shares knowledge that it is cost effective also and helps librarians to access all needs of their users well.

\section{DEFINITION}

(Hirshon, 1999) This term is mainly indicated that all book centres need to associate with others to share their books with each other and also raises the level of service. This system mainly gives modified structure to all athenaeums and improves their inner part functioning completely. It gives their facilities of loans so that all of them are capable of enrolling their name in this association and enjoys benefits of this correctly.

It helps to assess digital format to their centres well and it helps to access all particulars about each other. It gives contemporary structure to their information centre. This term is mainly defined where so many organisations worked together as a joint venture and performed for each other to raise the profit rate of an individual accordingly.

\section{ADVANCEMENT OF ASSOCIATION}

LC-------IL----------DDS-------LN------LC

\section{Delimitation of the Study (Scope)}

The topic of the research study is "Library Consortia Special Reference to Engineering College Library: A Study of West Bengal" to collect for this study, faculty members, research scholars, and Engineering College Users of West Bengal. The area of the study focused on approximately One Hundred Twenty Engineering Colleges of West Bengal. The geographical 
area of this study is confined only to West Bengal Engineering colleges. This study is related to the Library Consortia Special Reference to Engineering College Library: A Study of West Bengal.

\section{METHODOLOGY}

The examination was prepared in such a way that it aids in gathering relevant particulars for the topic "Library Consortia Special Reference to Engineering College Library: A Study of West Bengal”. These documents were sanded to the Engineering institution and to all fresher's, philosophers and professors of West Bengal. It takes time to fill all these survey portions well and needs to be prompted accordingly. It has been found that after all these processes, there are a total of $\mathbf{6 6}$ institutions and 3468 customers filled all these documents and send all this feedback correctly. On that, all these particulars checked thoroughly and calculated statistical calculations well, which is needed for this particular work.

\section{General Information of Engineering Colleges in West Bengal}

Table 1: Gender-Wise Library Professional (Statistical Analysis)

\begin{tabular}{|l|l|l|l|}
\hline S. No. & Gender & Library Professional & Percentage \\
\hline
\end{tabular}

\begin{tabular}{|c|c|c|c|}
\hline 1. & Male & 42 & $63.63 \%$ \\
\hline 2. & Female & 24 & $36.36 \%$ \\
\hline & Total & $\mathbf{6 6}$ & $\mathbf{1 0 0}$ \\
\hline
\end{tabular}

Table 1 reveals that the Engineering College Libraries Out of the 66 Engineering College Libraries Professional. The Gender-wise distribution of the overall Professionals reveals that considering their gender, the majority are Male 42 $(63.63 \%)$ as the female populace consists of $24(36.36 \%)$ only.

\section{Need of Library Consortia}

- Information Explosion

- Shrinking Budget

- Diversity of User Needs

- Professionalization of Library Services

- Quick Access

- Impossibility of self- Sufficiency

- Readiness of correspondent.

- Modify the constitution of investigation.

- Future Developments

Issue Related to Consortia

- $\quad$ Network problems are one of the major issues of this system.

- It is expensive and all of them do not have that much funding to enrol their names in this association.

- Licensing is one of the major drawbacks of this council. 
- $\quad$ This term and management of this system are not known clearly to the public, therefore popularity and demand are lower in public.

\section{Consortia Approach Digital Format Material in Engineering Institution}

The development of E-Resources in particular the intellectual literature with similar advances in ICT facilitated with earlier access to and delivery of information to libraries and publishers have adopted an original approach to provide E-Resources access and services to the users through E-Resources consortia. Over the previous years, an important transformation has been noticed in collection development policies and practices. This association helps each individual for getting references and important articles for their studies particularly. Most of the researchers provided their papers on relevant websites, from where students can refer to the full content for accomplishing their research accordingly. It incorporates:

Some of the major Consortia in electronic full-text journals publishing include

- $\quad \mathrm{ABI} /$ Inform Complete (Pro Quest) (http://www.il.proquest.com/pqdauto)

- Academic Press (Ideal Library); http;//www.idealibrary.com

- Association for Computing Machinery (ACM): www.acm.org

- American Chemical Society (ACS)- $\underline{\text { http://pubs.acs.org/ }}$

- American Physical Society(APS)- http://publish.aps.org/

- American Society for Civil Engineers (ASCE)- $\underline{\mathrm{http}: / / \mathrm{www} . a s c e . o r g}$

- Association for Mechanical Engineers (ASME)- http://asmedigitalcollection.asme.org

- $\quad$ ASTM Digital Library (ASTMDL) - http://enterprise.astm.org

- Business Source Elite (EBSCO)- $\underline{\text { http://search.ebscohost.com }}$

- DEL (www.digitalengineeringlibrary.com)

- Elsevier Science publishers (Science Direct)- http://www.sciencedirectcom/

- Emerald Insight- www.emeraldinsight.com

- $\quad$ EI Compendia Plus (Engineering Village 2) (http://www.engineeringvillage2.org/)

- INSPEC on eye Village (http://www.ei.org/ev2/home)

- The Institution of Engineering and Technology (IET)- www.theiet.org

- Institute of Electrical \& Electronics Engineers (IEEE)- http://ieeexplore.ieee.org

- Journal Gateway (J-Gate)- http://www.jgate.in J-Gate Custom Content for Consortia (JCCC) (http://jcccindest.informindia.co.in/)

- McGraw-Hill Access Engineering - http://accessengineeringlibrary.com

- $\quad$ Springer Vela (Link Electronic Service) - http://link.springer.de/

- Springer-www.springer.com 
- Wiley Inter science- $\mathrm{http}: / /$ www.Wiley.com/

Digital Library Consortia are operating in India now and the example of the consortia for engineering and technology institutions is the

- INDEST: Indian National Digital Library in Engineering and Science and Technology was set up in 2003, (paniit.iitd.ac.in/incest/).

Table 2: Subscribing Online Journals in Consortia Mode

\begin{tabular}{|c|l|c|c|}
\hline S. No. & \multicolumn{1}{|c|}{ Consortia Mode } & $\begin{array}{c}\text { Yes } \\
\text { (Frequency out of 66 } \\
\text { Colleges) }\end{array}$ & Percentage \\
\hline 1. & $\begin{array}{l}\text { Improve the availability and accessibility of } \\
\text { journals }\end{array}$ & 32 & 48.48 \\
\hline 2. & $\begin{array}{l}\text { Help to achieve Universal Bibliographical } \\
\text { Control }\end{array}$ & 20 & 30.30 \\
\hline 3. & $\begin{array}{l}\text { Reduce the gap between rich and poor } \\
\text { libraries in case of information from } \\
\text { journals/databases }\end{array}$ & 10 & 15.15 \\
\hline 4. & $\begin{array}{l}\text { Reduce the time lag in providing } \\
\text { information service }\end{array}$ & \multicolumn{1}{c}{ Total } & \multicolumn{1}{|c|}{6.06} \\
\hline
\end{tabular}

The analysis of data of Table No. 2 indicates that out of 66 colleges, 32 (48.48\%) College Subscribing Online Journals in Consortia Mode in Engineering College Library to reasons improve the Availability and Accessibility of Journals, 20 (30.30\%) College Subscribing Online Journals in Consortia Mode in Engineering College Library to reasons Help to Achieve UBC, 10(15.15\%) College Subscribing Online Journals in Consortia Mode in Engineering College Library to reasons reduce the gap between rich and poor Libraries Information from Journals/ Database, 4 (6.06\%) College Subscribing Online Journals in Consortia Mode in Engineering College Library to reasons reduce the Time lag in Providing Information Service.

Table 3: Structure of Council for Programmed Review Beneficial More Succession in 1, 2 , 3 Sequence

\begin{tabular}{|c|c|c|c|}
\hline Sl. No. & Consortia for Electronic Journals Benefit & $\begin{array}{c}\text { Frequency out of } 66 \\
\text { College }\end{array}$ & Percentage \\
\hline 1. & $\begin{array}{l}\text { Single Academic and Research Library } \\
\text { Consortium for the whole country (not for } \\
\text { private sector Research. }\end{array}$ & 10 & 15.15 \\
\hline 2. & $\begin{array}{l}\text { One information centre conference for } \\
\text { investigation centres in this nation. }\end{array}$ & 25 & 37.87 \\
\hline 3. & $\begin{array}{l}\text { Separate examination bibliotheca for several } \\
\text { states of this country. }\end{array}$ & 10 & 15.15 \\
\hline 4. & $\begin{array}{l}\text { Different athenaeum council for different class } \\
\text { that includes } U G C, C S I R, D R D O, I C A R \text {, } \\
\text { ISRO, ICSSR, etc. }\end{array}$ & 21 & 31.81 \\
\hline \multirow[t]{2}{*}{5.} & Any other system of Library Consortium & - & \\
\hline & Total & 66 & 100 \\
\hline
\end{tabular}

These particulars help to analyze that, 66 colleges, 10(15.15\%) college system of association in mechanised paper will be advantageous in Engineering institution unaccompanied bibliotheca for the entire nations and it is strict only in that not for individual examination, 25 (37.87\%). College Systems of Consortia for Electronic Journals will Benefit in 
Engineering College to One Library Consortium each for academic and research institutions in the country,10 (15.15\%) College Systems of Consortia for Electronic Journals will benefit in Engineering College to Different athenaeum council for different class that includes UGC, CSIR, DRDO, ICAR, ISRO, ICSSR, etc.

Table 4: Library Network using for Resource Sharing

\begin{tabular}{|c|l|c|c|}
\hline SI. No. & Library Network & Frequency out of 66 College & Percentage \\
\hline 1. & Inflibnet & 15 & 22.72 \\
\hline 2. & Delnet & 20 & 30.30 \\
\hline 3. & Calibnet & 15 & 22.72 \\
\hline 4. & Bonet & 5 & 7.57 \\
\hline 5. & Mylibnet & 6 & 9.09 \\
\hline 6. & Malibnet & 5 & 7.57 \\
\hline 7. & Any Other & - & - \\
\hline \multicolumn{2}{|c|}{ Total } & 66 & 100 \\
\hline
\end{tabular}

The analysis of data of Table No. 4 indicates that out of 66 colleges, 15 (22.72\%) College INFLIBNET Library Network using for Resource sharing, 20 (30.30 \%) College DELNET Library Network using for Resource sharing, 15 (22.72\%) College CALIBNET Library Network using for Resource sharing, 5(7.57\%) College BONET Library Network using for Resource sharing, 6 (9.09\%) College MYLIBNET Library Network using for Resource sharing, 5 (7.57\%) College MALIBNET Library Network using for Resource sharing in Engineering College.

Table 5: Library Consortia

\begin{tabular}{|c|l|c|c|}
\hline S. No. & Library Consortia & Frequency out of 66 college & Percentage \\
\hline 1. & Csir & 5 & 7.57 \\
\hline 2. & Inflibnet & 10 & 15.15 \\
\hline 3. & Ugc Infonet & 15 & 22.72 \\
\hline 4. & Helnet & 5 & 7.57 \\
\hline 5. & Ugc-Dae & 10 & 15.15 \\
\hline 6. & Indest -Aicte & 21 & 31.81 \\
\hline 7. & Any Other & - & - \\
\hline \multicolumn{2}{|c|}{ Total } & $\mathbf{6 6}$ & $\mathbf{1 0 0}$ \\
\hline
\end{tabular}

The analysis of data of Table No. 5 indicates that out of 66 colleges, 5 (7.57\%) College CSIR Consortia used in Engineering College Library, 10 (15.15\%) College INFLIBNET Consortia used in Engineering College Library, 15 (22.72 \%) College UGC INFONET Consortia used in Engineering College Library, 5 (7.57 \%) College HELNET Consortia used in Engineering College Library, 10 (15.15\%) College UGC DAE Consortia used in Engineering College Library and 21 (31.81\%) College INDEST-AICTE Consortia used in Engineering College Library.

\section{E-RESOURCES}

Table 6: Engineering College Library Know About Library Consortium in India Statistical Analysis (Library Consortia)

\begin{tabular}{|c|c|c|c|}
\hline Sl. No. & & Frequency out of 66 College & Percentage \\
\hline 1. & Yes & 38 & 57.58 \\
\hline 2. & No & 28 & 42.42 \\
\hline & & 66 & 100 \\
\hline
\end{tabular}

The analysis of data of Table No. 6 indicates that out of 66 colleges, 38 (57.58 \%) Engineering College Library Know about Library Consortium in India, and 28(42.42\%) Engineering College Library is not aware of Library 
Consortium in India.

Table 7: Engineering College Library Know About Library Consortium in India Statistical Analysis (Library Consortia)

\begin{tabular}{|c|c|c|c|}
\hline S. No. & & Frequency out of 66college & Percentage \\
\hline 1. & YES & 38 & 57.58 \\
\hline 2. & NO & 28 & 42.42 \\
\hline & & 66 & 100 \\
\hline
\end{tabular}

The analysis of data of Table No. 7 indicates that out of 66 colleges, 38 (57.58 \%) Engineering College Library Know about Library Consortium in India, and 28(42.42\%) Engineering College Library is not aware of Library Consortium in India.

Table 8: Library Consortia (Statistical Analysis)

\begin{tabular}{|c|l|c|c|}
\hline Sl. No. & \multicolumn{1}{|c|}{ Library Consortium } & Frequency out of 66 college & Percentage \\
\hline 1. & Know about Library Consortia & 38 & 57.57 \\
\hline 2. & The library has sufficient E-resources for users & 48 & 72.72 \\
\hline 3. & Users are more benefited by E-resources than printed resources & 40 & 60.60 \\
\hline
\end{tabular}

The analysis of data of Table No. 8 indicates that out of 66 colleges, 38 (57.58 \%) Engineering College Library Know about Library Consortium in India, and 28(42.42\%) Engineering College Library is not aware of Library Consortium in India.

The analysis of data of Table No. 8 indicates that out of 66 colleges, 48 (72.72\%) and engineering College Library Sufficient E-Resources for Users.

The analysis of data of Table No. 8 indicates that out of 66 colleges, 40 (60.60\%) Engineering College Library Users are more benefited by E-Resources than the Printed Resource.

Table 9: Library Consortia is useful for Libraries

\begin{tabular}{|c|l|c|c|}
\hline S. No. & Library Consortia & Frequency out of 66 college & Percentage \\
\hline 1. & Very Useful & 40 & 60.60 \\
\hline 2. & Not Useful & 08 & 12.12 \\
\hline 3. & Useful & 18 & 27.27 \\
\hline & Total & $\mathbf{6 6}$ & $\mathbf{1 0 0}$ \\
\hline
\end{tabular}

The analysis of data of Table No. 9 indicates that out of 66 colleges, 40 (60.60\%) Library Consortia is very useful for Engineering College Library for Library, 18 (27.27 \%) Library Consortia is useful for Engineering College Library for Library.

Table 10: Satisfying Needs of Users about Library Consortia (Statistical Analysis)

\begin{tabular}{|c|l|c|c|}
\hline Sl. No. & Library Consortia & Frequency out of 66 college & Percentage \\
\hline 1. & Yes & 43 & 65.15 \\
\hline 2. & No & 06 & 9.09 \\
\hline 3. & Almost & 17 & 25.75 \\
\hline & Total & $\mathbf{6 6}$ & $\mathbf{1 0 0}$ \\
\hline
\end{tabular}

The analysis of data of Table No. 10 indicates that out of 66 colleges, 43 (65.15\%) Library Consortia Satisfying 
needs of Users in Engineering College Library.

Table 11: Think Consortium Is Best 'Tool for Library Users For E-Resources (Statistical Analysis)

\begin{tabular}{|c|l|c|c|}
\hline S. No. & Library Consortia & Frequency out of 66 college & Percentage \\
\hline 1. & Yes & 41 & 62.12 \\
\hline 2. & Most of the Time & 13 & 19.69 \\
\hline 3. & Some Time & 5 & 7.57 \\
\hline 4. & No & 7 & 10.60 \\
\hline & Total & $\mathbf{6 6}$ & $\mathbf{1 0 0}$ \\
\hline
\end{tabular}

The analysis of data of Table No. 11 indicates that out of 66 colleges, 41 (62.12\%) Engineering College of Library Consortia Best tool for Library Users for E-Resources and 13 (19.69\%) Engineering College of Library, most of the Time Consortia Best tool for Library Users for E-Resources.

Table 12: Promote use of E-Resources within Institution (Statistical Analysis

\begin{tabular}{|c|l|c|c|}
\hline S. No. & E-resources & Frequency out of 66 college & Percentage \\
\hline 1. & Provide links from the home page & 11 & 16.66 \\
\hline 2. & Conduct orientation program from the home page & 5 & 7.57 \\
\hline 3. & Conduct orientation program for users & 5 & 7.57 \\
\hline 4. & E-mail/Internet mailing link & 45 & 68.18 \\
\hline & Total & $\mathbf{6 6}$ & $\mathbf{1 0 0}$ \\
\hline
\end{tabular}

The analysis of data of Table 12 indicates that out of 66 colleges, 05 (7.57\%) Engineering College Library Conduct Orientation Programme from Home page use for Promote use of E-Resources within Engineering College, 5 (7.57\%) Engineering College Library Conduct Orientation Programme for Users for Promote use of E-Resources within Engineering College, 45 (68.18 \%) Engineering College Library E-Mail/ Internet mailing Link use for Promote use of EResources within Engineering College and 11 (16.66\%) Engineering College Library Provide Links from Home Page use for Promote use of E-Resources within Engineering College.

\section{AIM \& BENEFITS OF E-JOURNAL CONSORTIA}

- The main aim of this system is that it helps to track the IP address and ID of each user correctly.

- It gives an opportunity that an individual easily accessed non subscribed puff's well.

- Consortia models offered by the publishers may help in (Benefit of cross-sharing, Resource increase by depth (Black Volume) \& breadth (non-subscribed titles) to consortium members and Negotiable price for subscribing titles)

- The final aim of any e- Journal consortia is to make online journal literature available to unreachable medical scholars working in the country through electronic media.

- Assist in better management of information resources in the electronic environment.

- Spreading of this notebook is economical and well organised also.

\section{CONCLUSIONS}

Thus, it can be concluded that all information centres need modification in their structures and internal function so that all 
of these centres can fulfil the needs of their users well. On that, one single system cannot provide all assets to their students for that reason collaboration is needed within 2 or more libraries. It aids to work as a team and gives an opportunity to share their association resources with each other. It has been found that the council helps in this matter so that an easy joint venture is formed and served from each other accordingly. It modifies the services and functions of all this athenaeum and helps to reduce their financial cost as all of them are performed collaboratively and decreases the needed amount of cost in an individual for subscription of this council particularly. This system also gives the platform of using the digital medium to access all references and books correctly. Further, it concluded that it improves the technological access of all bibliotheca and encourages them to work more untimely to give the best assistance to each user. This gives beneficial effects to all the information centres to adopt new technologies for the development of their services and raises the numbers of users correctly.

\section{REFERENCES}

1. Chartron, G. (2001). Electronic resources and documentary consortia: a survey of French scientific institutions. Journal of Librarianship and Information Science,33(2), 85-97. Retrieved on: 23rd March 2021, Retrieved from: https://journals.sagepub.com/doi/abs/10.1177/096100060103300205

2. Hirshon A, Libraries, Consortia, and change management, Journal of Academic Librarianship. 25(2) (1999), 124-166. Retrieved on: 23rd March 2021, Retrieved from: https://www.sciencedirect.com/science/article/pii/S0099133312001449

3. Janakiraman, S. (2002). Thoughts on Library Consortium'. Proceedings of the Round Table on Sharing of E-journals through Consortia in Indian Libraries, Bangalore, 28-29. Retrieved on: 23rd March 2021, Retrieved from: http://op.niscair.res.in/index.php/ALIS/article/view/308

4. Kent, Allen. (1978). Encyclopedia of Library and Information Science. New York: Dekker

5. Kunwar Singh V Bhaskar Rao. An Overview of the Library Consortia in India, Retrieved on: 23rd March 2021, Retrieved from: http://ir.inflibnet.ac.in/bitstream/1944/1124/1/10.pdf

6. Oxford Advanced Learners English Dictionary P.250, UK.

7. Rajawat, K., \& Gujran, M. N. LIBRARY RESOURCES AND SERVICES IN ENGINEERING COLLEGE LIBRARY SPECIAL REFERENCE TO SHEKHAWATI AREA IN RAJASTHAN: A CASE STUDY, 1-24, Retrieved on: 23th March 2021, Retrieved from: http://shabdbooks.com/gallery/241-july2020.pdf

8. Rajawat, Kumkum, \& Gujran, Neetu, Library Network and Consortia in India Special Reference to Shekhawati Area in Rajasthan. MuktShabd 10(9), September 2020.

9. Rajawat, Kumkum, Library Consortia Special reference in Medical college Library: A study, Information Resources, and Services in Digital Environment-ISBN - 978-81-7611-758-6, 2017

10. Saini, Anju. Library Consortia: An Overview. International Journal of Digital Library Services.7(4), October- December 2017. Retrieved on: 23th March 2021, Retrieved from: www.ijodls.in

11. Vasishta, Seema and Kaur, Manider, Implications of Library Consortia: How the Indian Libraries are benefited?, 1-9. Retrieved on: 23th March 2021, Retrieved http://eprints.rclis.org/17504/3/Implications\%20of\%20Library\%20Consortia.pdf

12. wikipeida.org (2021), Consumerism, Retrieved on: 23th March 2021, Retrieved from: http://www.en.wikipeida.org/wiki.Consortium. 


\section{ABBREVIATION}

- $\quad \mathrm{LC}=$ Library Cooperation

- $\mathrm{IL}=$ Interlibrary Loan

- DDS= Document Delivery System

- $\mathrm{LN}=$ Library Networks

- $\quad \mathrm{LC}=$ Library Consortia 